\title{
Management of Skull Base Osteoradionecrosis
}

\author{
Sung-Woo Cho ${ }^{(D)}$ and Tae-Bin Won $(D)$ \\ Department of Otorhinolaryngology-Head and Neck Surgery, Seoul National University Bundang Hospital, Seongnam, Korea
}

\section{두개저 방사선골괴사의 치료}

조성우 · 원태빈

서울대학교 의과대학 이비인후과학교실, 분당서울대학교병원 이비인후과

\author{
Received February 4, 2020 \\ Revised February 17, 2020 \\ Accepted February 19, 2020 \\ Address for correspondence \\ Tae-Bin Won, MD, PhD \\ Department of Otorhinolaryngology- \\ Head and Neck Surgery, \\ Seoul National University \\ Bundang Hospital, \\ 82 Gumi-ro 173beon-gil, \\ Seongnam 13620, Korea \\ Tel $+82-031-787-7401$ \\ Fax +82-31-787-4057 \\ E-mail binent@hanmail.net
}

Osteoradionecrosis of the skull base (SB-ORN) is a serious potentially lethal complication after radiotherapy in the head and neck region and is therefore considered one of the most challenging clinical entities among skull base lesions. Management options includes nasal irrigation, medications such as systemic antibiotics and anti-inflammatory drugs, hyperbaric oxygen therapy, and surgical debridement. Despite these efforts treatment outcomes are associated with a poor prognosis. Recent studies have shown an increased disease control rate with a more aggressive surgical approach including sequestrectomy. One of the main factors associated with poor prognosis is involvement of the internal carotid artery near the skull base. Spontaneous carotid rupture is frequently associated with death and/or severe morbidity and also poses risk of profuse bleeding during surgery. In this article we will deliver a comprehensive review of SB-ORN, including pathophysiology, clinical features, and an update in treatment strategy. Korean J Otorhinolaryngol-Head Neck Surg 2020;63(2):51-8

Key Words Carotid artery · Debridement · Osteroradionecrosis · Sequestrectomy · Skull base.

\section{서 론}

방사선 치료(radiation therapy)는 비인두암 및 부비동암에 서 일차 치료(primary therapy) 또는 수술 후 보조적 치료법 (adjuvant treatment)으로서의 중요한 역할을 하고 있다. 하 지만 방사선 치료 후에 발생할 수 있는 두개저 방사선골괴사 (skull base osteoradionecrosis)의 경우 치료가 가장 까다로 운 합병증 중의 하나로 여겨진다. ${ }^{1)}$ 현재까지 알려진 방사선 치 료 후 발생하는 두개저 방사선골괴사의 유병률은 5.4 10.1\% 로 다양하게 보고되었으며, 흔히 접형골(sphenoid bone), 사 대(clivus), 측두골(temporal bone)을 침범한다고 알려져 있 다. ${ }^{1-5)}$ 내경동맥(internal carotid artery, ICA) 주변 조직의 침 윤이 있는 경우는 심한 출혈로 인한 사망에 이르게 되는 심

This is an Open Access article distributed under the terms of the Creative Commons Attribution Non-Commercial License (https://creativecommons.org/licenses/by-nc/4.0) which permits unrestricted non-commercial use, distribution, and reproduction in any medium, provided the original work is properly cited.
각한 합병증을 야기할 수 있어 더욱 주의를 요한다.

방사선골괴사는 전신 어디에서도 나타날 수 있으며, 하악 골(mandible)과 같이 치료 방법이 잘 정립되어 있는 부위도 있지만, 두개저의 경우 아직까지는 표준적인 치료 방침이 없 다. 두개저 방사선골괴사의 치료는 보존적 치료와 수술로 나 뉜다. 보존적인 치료로서 비강세척(nasal irrigation), 고압산 소치료(hyperbaric oxygen therapy, HBOT)를 시도하거나 전신 항생제 또는 혈류 개선제의 하나인 펜톡시필린(pentoxifylline)과 항산화제인 토코페롤(tocopherol)을 투여할 수 있 지만, 현재로서 치료 결과는 만족스럽지 않다. ${ }^{6}$ 수술 역시 다 양한 다양하게 시도되어 왔고, 광범위 부골 절제술(wide sequestrectomy)과 같은 적극적인 수술을 통해 치료 결과를 향 상할 수 있다는 보고들이 있고, 최근에는 내시경을 통한 두 개저 수술의 발전으로 인해, 수술 후 이환율(morbidity)을 최 소화하면서도 좀 더 적극적인 수술적 치료가 가능해졌다. ${ }^{1)}$

두개저 방사선골괴사에 대한 지식들이 축적되고 있으나 아 
직까지는 정립된 치료 가이드라인이 부재한 시점에서, 본 종 설에서는 두개저 방사선골괴사에 대한 기전, 위험요인 및 현 재까지 소개된 대표적인 치료 방법 및 결과를 확인해 보고, 현재까지의 서울대병원의 경험을 바탕으로 두개저 방사선골 괴사에 관한 향후 치료에 대해 기술하고자 한다.

\section{본 론}

많은 기술의 진보가 있었음에도 두개저 방사선골괴사는 비 과 및 두개저 외과의사들에게 있어서 가장 까다로운 질환 중 에 하나이다. ${ }^{4)}$ 두개저 방사선골괴사는 고용량의 방사선 치료 를 받은 후에 괴사되는 과정으로, 3 개월 이상 지속되면서 서 서히 진행되며 저절로 낫지는 않고, 암의 재발과는 관련이 없 어야 한다. ${ }^{7)}$ 동물모델을 통해서도 명확한 방사선골괴사는 자 연적으로 호전되지 않는다는 것이 입증된바 있다. ${ }^{8)}$

\section{병태생리(Pathophysiology of skull base osteoradionecrosis)}

초기에는 방사선 치료 후에 발생하는 방사선골괴사의 주요 병태생리로 감염을 고려하였고, 이는 항생제 치료의 근거가 되었다. ${ }^{9)}$ 하지만 1983년 Marx는 방사선 치료로 세포 및 세포 외 영역에서의 일련의 과정으로서 조직의 저혈류(hypovascularity), 저산소(hypoxia), 저세포성(hypocellularity)을 야 기하고, 궁극적으로는 조직이 붕괴되면서 만성적으로 치료가 되지 않는 병변이 발생된다고 하였다. ${ }^{10,11)}$ 즉 혈관내피세포 손 상으로 인한 혈관폐색 및 동맥내막염으로 인한 혈행 감소와 골수 내 정상세포의 감소, 영양 및 산소 공급의 결핍으로 인 한 지방변성과 섬유화 과정을 겪게 되고, 골막 비후화로 쉽게 벗겨지게 될 경우 골아세포 결핍으로 재형성(remodeling) 과 정의 이상이 생긴다. 이런 Marx의 3저 이론(저혈류-저산소저세포성)은 고압산소치료(HBOT)의 근거가 되었다. ${ }^{12)}$

1998년 Delanian은 방사선 치료로 인한 섬유모세포 활동 (fibroblast activity)의 활성화(activation)와 조절장애(dysregulation)가 일어나고, 이로 인해 섬유조직이 외부충격에 취 약할 수 있다는 방사선 유발성 섬유위축 이론(radiation-induced fibroatrophic theory)을 제시하였다. ${ }^{13)}$ 이후 여러 연구 자들에게 방사선골괴사의 주요 기전으로 인정받게 됨에 따라, 항산화제(antioxidant drug)와 항섬유화제(antifibrotic drug) 사용의 이론적 기반이 되었다. ${ }^{14)}$

종합적으로 방사선골괴사의 명확한 기전은 밝혀지지는 않 았지만, Marx의 3저이론과 Delanian의 방사선 유발성 섬유 위축 이론을 통해 설명되고 있고, 그 외 다양한 연구들을 통 해서 추가적인 병리기전을 설명하고 있으나 이에 대한 합의
는 부족하다. ${ }^{4)}$

\section{위험인자와 보호인자(Risk factors and protective}

\section{factors of skull base osteoradionecrosis)}

다양한 요인들이 두개저 방사선골괴사의 진행에 영향을 미 칠 수 있다. 먼저 위험인자로는 발생한 부위, 고용량의 방사선 치료, 고령, 남자, 흡연, 음주가 있다., ${ }^{5,915,16)}$ 보호인자로는 특이 하게도 골괴사를 일으킨다고 잘 알려진 스테로이드가 방사선 골괴사 예방에는 도움이 될 수도 있다. ${ }^{15,17)}$ 하지만 다양한 연 구 결과에도 불구하고 스테로이드의 용법 및 사용 기간 등에 대해 전향적인 연구들이 더욱 필요하다.

\section{진단(Diagnosis of skull base osteoradionecrosis)}

두개저 방사선골괴사는 임상적, 영상학적, 그리고 병리학적 인 내용을 근거로 진단한다. 두개저 방사선골괴사의 증상으 로는 두통이 가장 흔하고 악취, 가피 형성, 비출혈 및 복시와 같은 뇌신경 증상들이다 ${ }^{7,9)}$. 방사선 치료 후 발생률이 매년 증 가하는 양상인데, 첫해에는 $3 \%, 3$ 년 후에는 $5 \%, 5$ 년 후에는 $7 \%$ 에서 방사선골괴사가 발생한다고 알려져 있다. ${ }^{10)}$ 비인두와 같은 두개저 부위에 방사선 치료력이 있으면서 내시경 소견 에서 비인두의 화농성 분비물과 함께 괴사된 조직을 확인하 는 경우에 의심할 수 있는데(Fig. 1), 분비물을 제거하고 난 뒤에는 동반된 부골(bony sequestra)을 확인할 수 있다. 영상 검사의 전형적인 특징으로 두개저에 인접한 뼈에서 경화성 (sclerotic) 또는 미란성(erosive) 변화가 동반되면서 괴사된 연조직이 관찰되는데, 종종 내경동맥의 근위부에서 보일 수 있다(Fig. 2). 때로는 두개저 방사선골괴사과 잔류성(residual), 또는 재발성(recurrent) 종양과의 구별이 어렵기 때문에 확진 을 위해 생검을 실시하게 된다. ${ }^{18)}$

\section{치료(Treatment methods)}

보존적 치료 방법으로는 비강 세척, 전신 항생제나 항염증 성 약물의 투여, 또는 고압산소치료가 있고, 수술적 방법으로 는 접근법에 따라 개방 또는 내시경 접근법이 있고, 범위에 따 라 최소한의 연조직만 제거하는 변연절제술(debridement)에 서부터 적극적인 부골절제술(sequestrectomy)까지 다양하게 적용되고 있다.

두개저 방사선골 괴사에 대한 보존적인 치료의 결과는 다 양하기 때문에 아직까지 논쟁의 여지가 있다. 펜토시필린 (pentoxifylline, PTX)은 말초혈관 질환에 사용되고, 토코페 롤(tocopherol, TCP)은 항산화제로서 방사선골괴사의 증상 을 호전시키기 위해 사용되어 왔다.,8,19-21)

두 약물은 1998년 Delanian이 처음으로 조합하여 사용하 
였고 ${ }^{14)}$ 무작위 이중맹검 연구 $(\mathrm{n}=24)^{22)}$ 를 통해 특별한 부작용 없이, 방사선 유도 섬유화(radiation-induced fibrosis)가 감 소하는 것을 확인하였다. 그럼에도 불구하고, $\mathrm{PTX} / \mathrm{TCP}$ 조 합은 질환의 초기에서만 효과가 있고, 질병이 진행된 경우에 서 PTX/TCP 단독 요법은 질병이 진행되는 것을 막을 수 없 다고 알려져 있다. ${ }^{23)}$

클로드로네이트(clodronate, CLO)는 새로운 종류의 비스 포스포네이트(bisphosphonate)계 약물로서, 파골세포(osteoclast)의 숫자와 활동을 줄여 재흡수를 감소시켜 잠재적인 치료 약물로 여겨지고 있다. ${ }^{20,24-26)}$ 하지만 두개저 방사선골괴 사에 대한 효과는 아직까지는 정립되어 있지 않다.

$\mathrm{PENTOCLO}$ 요법은 PTX/TCP와 CLO를 병합하여 치료 하는 방법으로 Delanian에 의해 2002년부터 소개되었다. ${ }^{27)}$ 2011년 Delanian은 54명을 대상으로한 전향적 코호트 연구를 통해 9 개월 이내의 모든 환자는 완전히 회복했고, 부골절제
술을 받은 환자는 더 회복 과정이 빨랐다고 보고했다. ${ }^{28)}$

고압산소치료에 대한 효과는 다양한 혼재된 치료 결과로 인해 논쟁의 여지가 있다. 현재 두개저 방사선골괴사에 관한 단독 고압산소치료의 효과는 미미하다고 여겨지고 있으나, 변연절제술과 동반된 부가적 치료 방법으로서의 고압산소치 료의 효능은 확인되었다. ${ }^{29-31)}$ 보존적인 치료를 시행하였을 시 약 $9 \%$ 에서 보이는 점막결손이 내시경 검진과 MRI에서 호전 되는 소견이 있을 수 있지만, 이러한 경우에도 골괴사는 호전 이 잘 안되는 것으로 알려져 있기 때문에 보존적인 치료에 반 응을 하지 않아 두통 및 악취가 지속되고, 뇌막으로의 침범 및 출혈이 있을 경우 수술적인 치료를 시행할 것을 고려해야 한다. ${ }^{32)}$

적극적인 부골절제술(sequestrectomy) 수술 방법으로는 개방접근법으로서 상악회전법 ${ }^{32,33)}$ 과 내시경적 경비접근법이 있다. 개방접근법은 경동맥으로 접근하기가 용이하고, 예상치
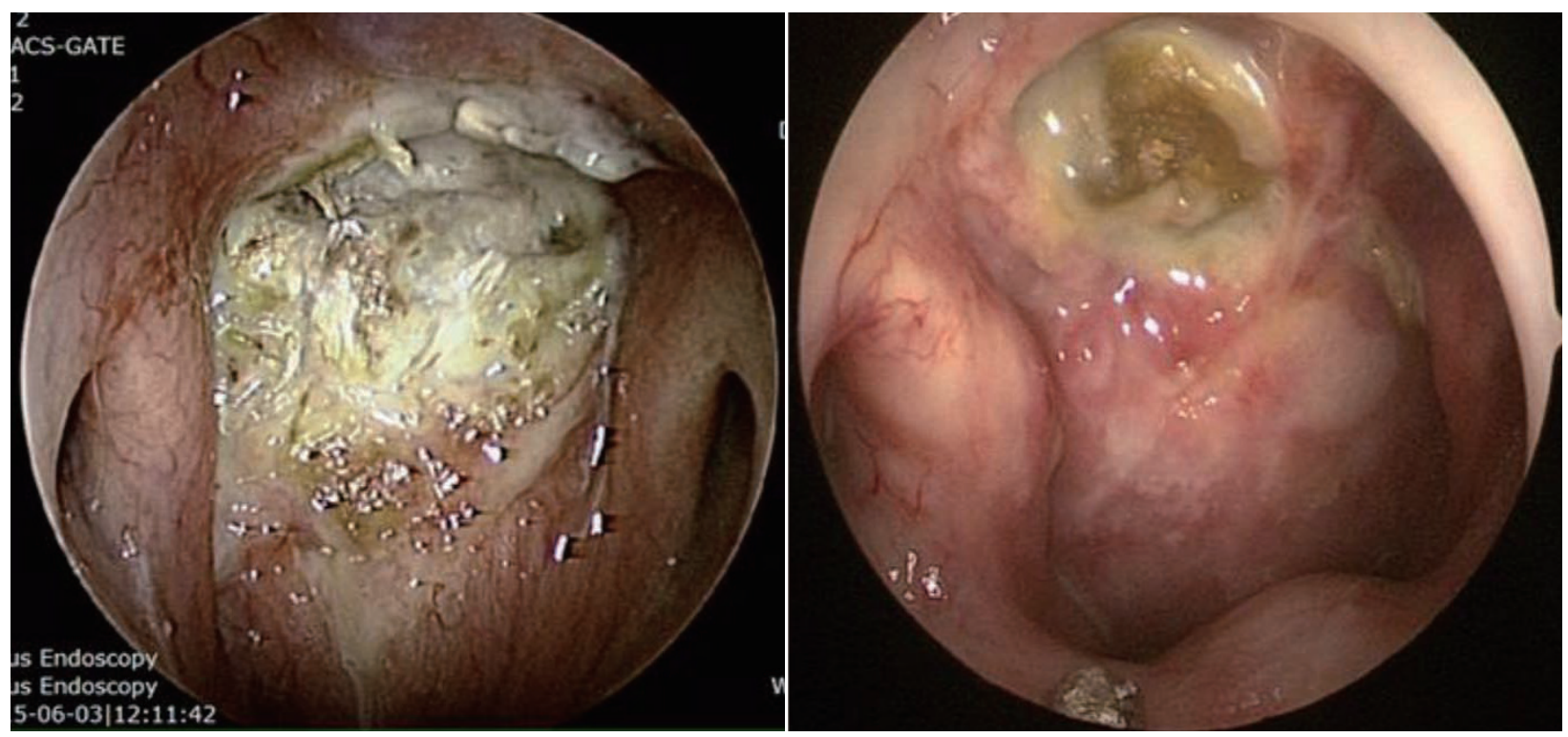

Fig. 1. Foul necrotic tissue with purulent secretion. Sequestra (exposed bone) can be seen after removal of secretion.
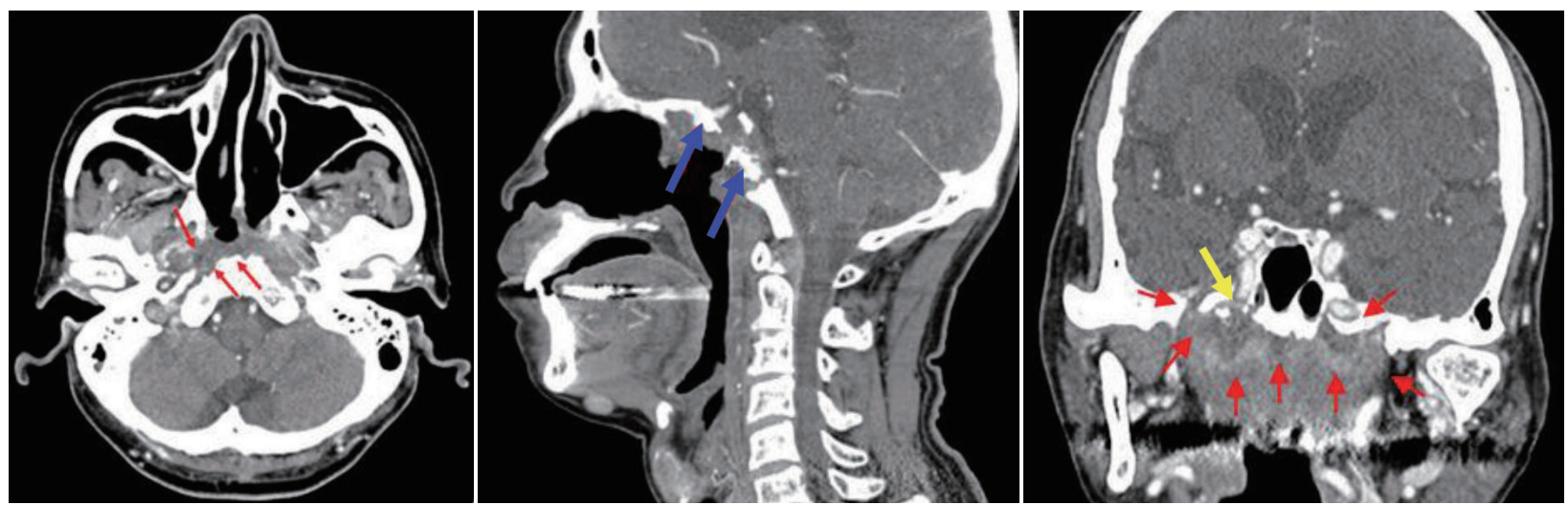

Fig. 2. Necrotic soft tissue (red arrows) with sclerotic and erosive changes of the adjacent bones of the skull base (blue arrows), proximity to the internal carotid artery (yellow arrow). 
못한 경동맥 손상 시 적절한 조치를 취할 수 있다. ${ }^{34}$ 수술시 외부로 드러난 골부를 확인할 수 있는데, 방사선 치료 후에 혈관내피세포 손상으로 인한 비정상적인 혈류 공급으로 인 해, 재생능력이 현저히 감소되어 있기 때문에, ${ }^{35)}$ 부골절제술 을 시행한 부분을 비점막피판(nasoseptal flap) 혹은 유리피 판 등, 혈류가 풍부한 조직으로 덮는 것이 중요하다.

최근 수술 방법의 발전으로 내시경적 경비접근법이 복부 두개저(ventral skull base) 병변에 접근하기 위한 혁신적인 방법으로 받아들여지고 있다. 개방하는 것에 비해 외부 흥터 를 피하고, 관련 없는 구조물들의 손상을 최소화하는 장점이 있고, 충분한 경험이 있을 경우 추체부 경동맥을 포함한 복 부 두개저 전체에 접근할 수도 있기 때문이다.

\section{내경동맥에 대한 처치(Management of internal carotid artery)}

두개저 방사선골괴사의 $50 \%$ 정도에서 괴사된 병변이 내경 동맥과 인접해 있으며, 내경동맥 파열로 인한 과다출혈이 사 망 원인 중 가장 많은 부분을 차지하는 것으로 알려졌다. ${ }^{2,36}$ 내경동맥의 침범이 있는 경우에 보존적인 치료만을 할 경우 질환의 진행으로 인해 약 $50 \%$ 정도의 환자에게서 경동맥 파 열로 인하여 사망할 수 있고, ${ }^{18)}$ 부골절제술과 같이 적극적인 치료를 하더라고 경동맥의 혈관외막(adventitia)이 괴사되고 약하기 때문에 최소한의 조작만으로도 경동맥 파열이 일어 날 수 있다. 따라서 모든 환자에서 내경동맥에 대한 평가가 필요하며 경우에 따라서 $\mathrm{CT}$ 혹은 MR angiography를 통하 여 혈관의 주행을 파악하고 위동맥류(pseudoanuerysm)와 같은 병변이 없는지를 확인할 수 있다(Fig. $3 \mathrm{~A}$ ). 내경동맥를 감싸는 골성 외벽이 파괴되어 내경동맥이 노출되어있거나, 괴 사된 조직으로 생각되는 병변과 닿아 있는 경우, 내경동맥의 내강(lumen)이 불규칙하거나, 혹은 위동맥류가 관찰되는 경 우 등, $\mathrm{CT} / \mathrm{MR}$ 영상상에서 내경동맥이 분명하게 침범이 된 경우 반드시 수술 전 혈관조영검사(angiography)를 하면서 풍선폐쇄검사(balloon occlusion test)를 하고서 single photon emission CT를 시행한다(Fig. 3B). 만약 뇌에서 저관류가 없는 경우, 내경동맥은 혈관내 코일 색전술(endovascular coil embolization)을 시행하여 막은 후 수술을 시행한다(Fig. 4). 만약 풍선폐쇄검사에서 저관류가 관찰되는 외경동맥과 내경 동맥의 우회로 이식술[external carotid artery-internal carotid artery(ECA-ICA) bypass]을 고려할 수 있다. ${ }^{37)}$ 일부의 경우 내경동맥 안으로 혈관 스텐트를 삽입한 후 2 3주 뒤에 수술을 진행하면 스텐트 주위로 신생혈관외막(neoadventitia)이 형성되어 병변으로부터 경동맥의 박리가 가능하다고 보고되고 있으나 내경동맥의 꼬임이 심한 경우 스텐트 삽입 으로 내경동맥의 파열이 생길 가능성이 있다. ${ }^{38)}$ 수술 전 내경 동맥 처치에 대한 알고리즘은 Fig. 5 로 요약할 수 있다.

\section{내시경적 경비적 외과적 변연절제술 수술 방법} (Endonasal endoscopic surgical procedures)

모든 수술은 네비게이션 시스템하 내시경적 경비접근법을 통해서 시행된다. 우선 부골절제술을 시행한 부분을 덮어주 기 위해서 대부분의 경우 병변의 반대측에서 비중격피판(nasoseptal flap)을 크게 거상한다. 후방 골중격을 절제한 후에, 주 병변의 동측의 비중격점막은 공여부를 덮기 위한 역행성 피판(reverse flap)으로 사용되어, 양측 비공(binostril access) 을 통해 넓게 비인두로 접근할 수 있다. 두개저와 비인두로의 더 많은 접근은 내시경 비인두 절제술과 유사한 방법으로 시 행된다. 동측의 접형구개동맥(sphenopalatine artery)에 대해 적절한 조절을 하고, 상악동절개술(maxillary antrostomy)와
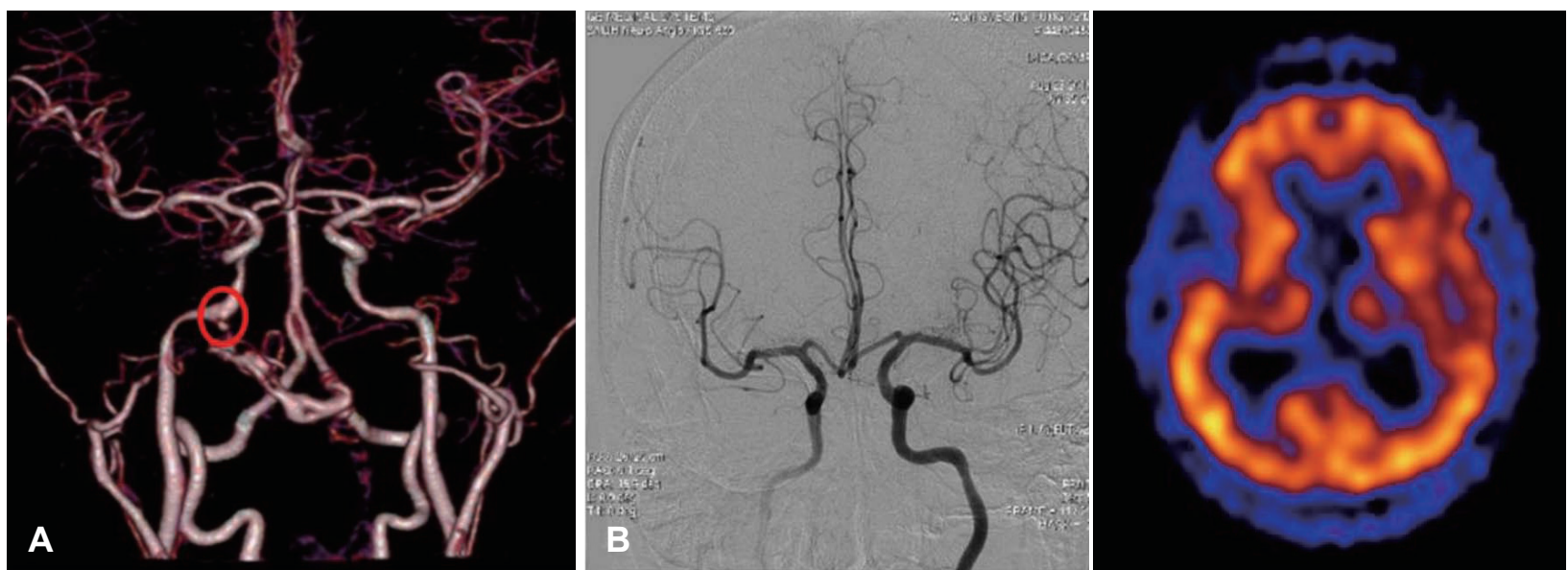

Fig. 3. Preoperative evaluation of internal carotid artery. Pseudoaneurysm (circle) identified by MR angiography (A). Right internal carotid artery balloon occlusion test and SPECT. Good collateral via anterior communicating artery is identified and SPECT image shows no brain hypoperfusion (B). SPECT: single photon emission CT. 


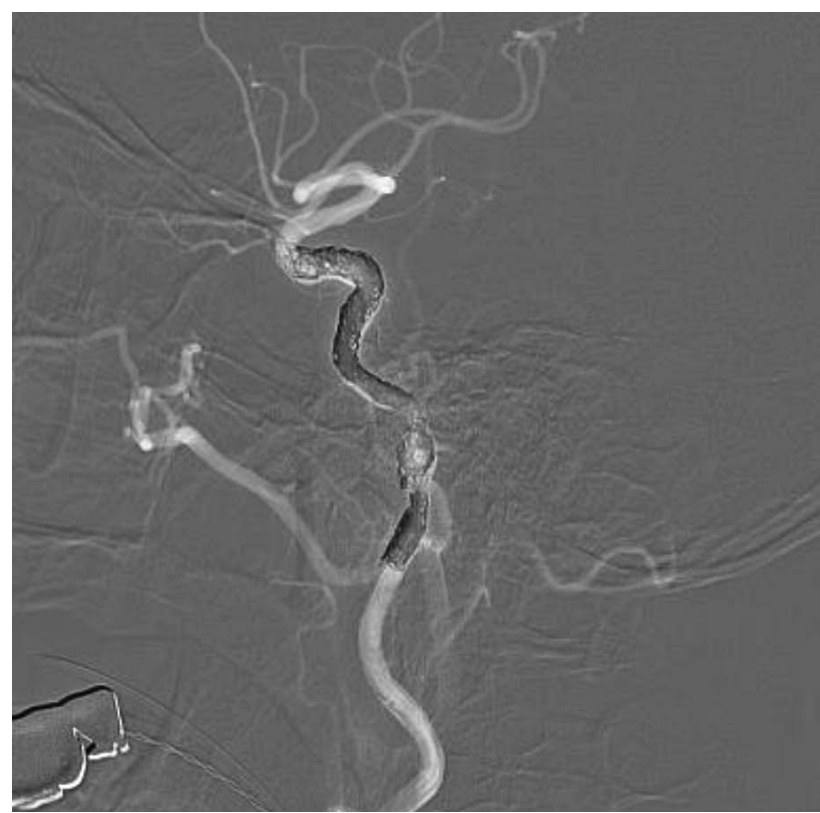

Fig. 4. Right internal carotid artery coiling and embolization.

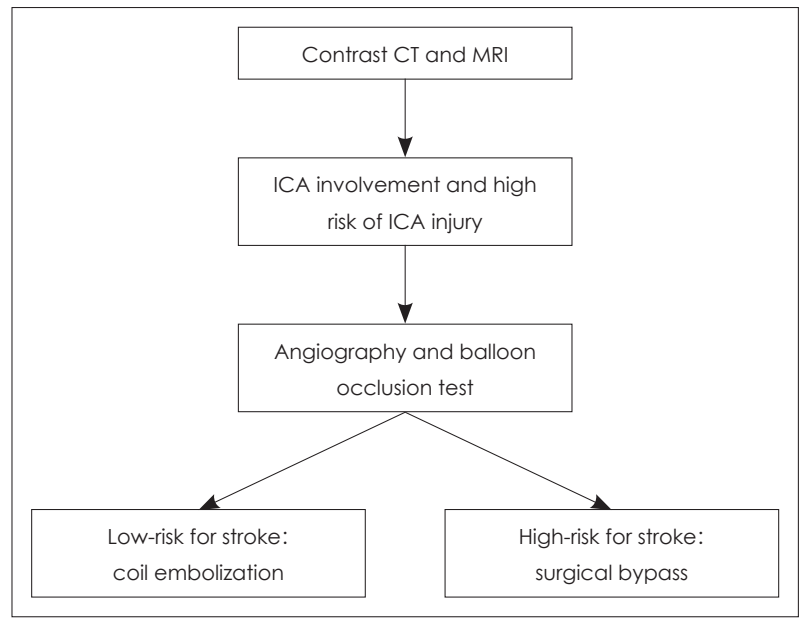

Fig. 5. Surgical planning algorithm for high risk ICA injury in skull base osteoradionecrosis. High risk ICA injury includes; irregular shape of the lumen of the artery, the presence of a pseudo-aneurism, ICA no longer covered by bone, or exposed to necrotic soft tissues. Patients with high risk ICA injury should be evaluated with angiography with balloon occlusion test. If there is enough collateral and the risk of stroke is low when occluded, coil embolization can be performed. However if the collateral circulation is limited and the risk of stroke is high, a surgical bypass should be considered. ICA: internal carotid artery.

접형골동절개술(sphenoidotomy)을 시행한다. 이후 상악동 의 후벽과 구개골(palatine bone)의 눈확돌기(orbital process) 를 제거하고, 익구개와(pterygopalatine fossa)를 노출시킨다. 익구개와의 구조물은 원형공(foramen rotundum)과 익돌관 (vidain canal)을 노출하기 위해 측면으로 이동시킨다. 추가 적인 측면 노출은 병변 범위에 따라 결정된다. 괴사된 연조직 은 겸자, 큐렛, 절삭흡입기(microdebrider)를 이용하여 제거

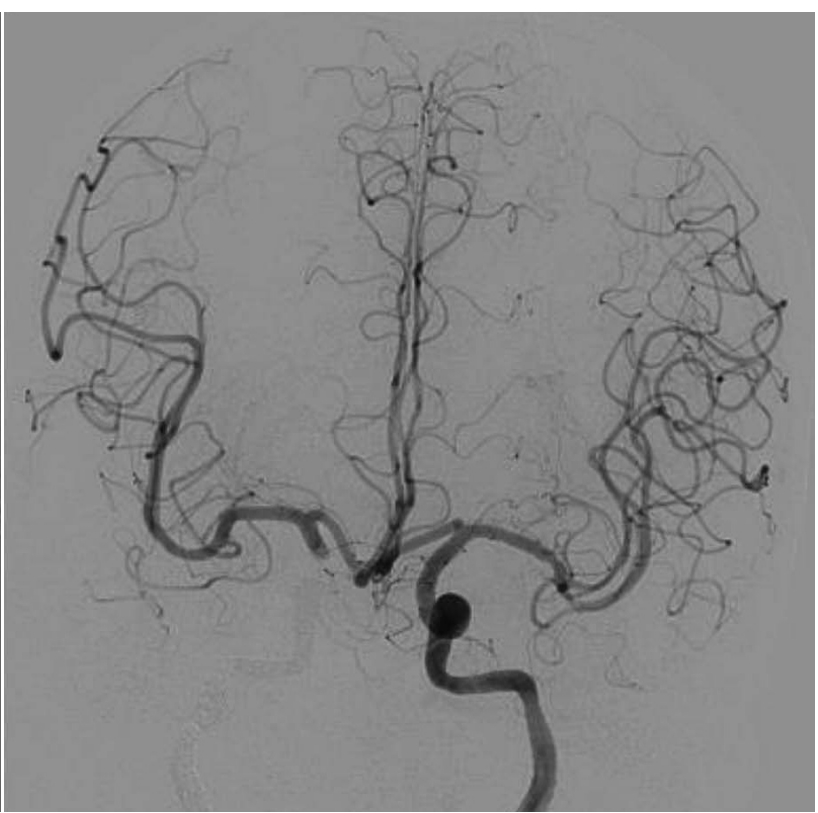

한다. 괴사된 조직이 경동맥을 침범한 경우 이를 감안하여 반 드시 조심스럽게 절제를 해야 한다. 조직절제는 병변이 침범 한 점막, 인두결절근막(pharyngobasilar fascia), 두장근(longus capitis), 경장근(longucs colli), 두직근(rectus capitis), 연골부 이관(cartilagineous E-tube), 구개범장근(tensor veli palatini), 구개범거근(levator veli palatine), 파열공 인근의 섬유연골 조직(fibrouscartilaginous tissue)의 정도에 따라 다르다. 부골은 드릴을 이용하여 중심부부터 시작하여 피가 날 때까지 제거한다. 가장 흔한 골제거 부위는 접형골의 바닥, 사대골, 측두골의 추체부(petrous part of the temporal bone) 이다. 괴사된 조직을 완전히 수술로 제거하고 난 후, 노출된 두개저와 내경동맥을 비중격피판을 덮어 준다(Fig. 6).

\section{치료 결과(Treatment outcome of skull base osteoradionecrosis)}

이러한 다양한 노력에도 불구하고, 두개저 방사선골괴사의 치료 결과는 좋지 못하다. 보고된 바에 따르면 2년 전체 생존 율은 $54.2 \%^{2}$ 이고, 보존적 치료만 하는 경우는 수술적 치료 보다 예후가 더 나빠 보인다. ${ }^{18)}$ 하지만, 치료 결과를 호전시킬 수 있는 뚜렷한 방법에 대한 연구가 부족하기 때문에, 두개저 방사선골괴사에 대한 최적의 치료에 대한 합의는 아직까지는 없는 상황이다.

\section{서울대병원의 경험}

2006년 1월 2017년 2월까지 비인두 또는 부비동암의 방사 선 치료 후, 두개저 방사선골괴사로 진단된 환자 15 명을 대상 

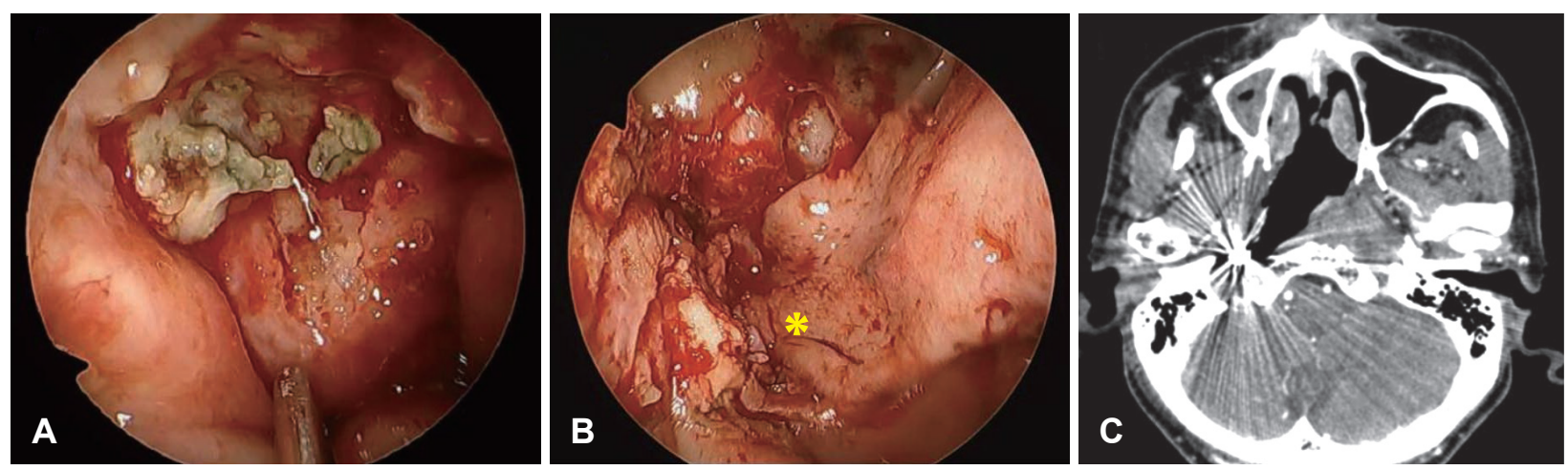

Fig. 6. ICA trapping with coil embolization and endoscopic endonasal sequestrectomy followed by coverage with a nasoseptal flap. Endoscopic findings of skull base osteoradionecrosis (A). Coverage with a pedicled nasoseptal flap after aggressive debridement and sequestrectomy (B). Follow-up zxial CT scan shows trapping of the right ICA and extent of skull base debridement (C). *: a nasoseptal flap, ICA: internal carotid artery.

으로 한 연구를 잠깐 소개하고자 한다. 이는 임상시험윤리위 원회 프로토콜(IRB No. 2013-0105)에 따라 이루어진 연구 이며, 환자의 평균 나이는 62.9세로, 방사선 치료를 종료하고 난 이후 두개저 방사선골괴사로 진단받기까지 평균 37.8개월 이 소요되었다. 가장 흔히 호소하는 증상은 두통(11/15)이었 고, 그 다음은 악취(5/15)였다. 10명의 환자(10/15, 66.7\%)에서 내경동맥이 침범된 것을 확인하였고. 평균 생존 기간은 13.2 개월(95\% confidence interval 8.07 18.36 mon), 2년 평균 생 존율은 30.4\%였다. 치료는 보존적 치료(conservative treatment)와 적극적 치료(aggressive treatment)로 분류하였다. 보존적 치료에는 고압산소치료, 약물치료, 최소한의 연조직 변연절제술이 포함되었고, 적극적 치료에는 연조직과 부골의 수술적 절제 후 혈관이 풍부한 조직을 덮어주는 경우로 정하 였다. 두 치료군 간의 기저질환, 나이, 방사선 조사량, 그리고 경동맥 침범 정도에서 유의한 차이는 발견되지 않았다. 적극 적 치료를 받은 그룹(7/15)에서 2년 생존율은 $75 \%$ 였으나, 보 존적인 치료 그룹(8/15)에서는 2년 후 생존한 환자는 없었다 (log rank $p=0.029)$ (Fig. 7). 보존적인 치료를 받았던 8명 중 3 명에서 경동맥 파열이 있었으나, 적극적 치료를 받았던 그 룹에서는 없었다. 경동맥 파열이 있었던 환자는 모두 사망하 였다.

\section{결 론}

두개저 방사선골괴사 치료의 주요한 쟁점은 경동맥, 특히 추체부 경동맥에 대한 관리이다. 본 연구에서 볼 수 있듯이, 경동맥 파열은 두개저 방사선골 괴사의 가장 치명적인 원인 이다. 경동맥의 침범이 있는 경우에 적극적인 치료를 하지 않 으면 질환의 진행으로 인한 경동맥 파열로 인하여 사망할 수 있고, 부골절제술과 같이 적극적인 치료를 하더라고 경동맥

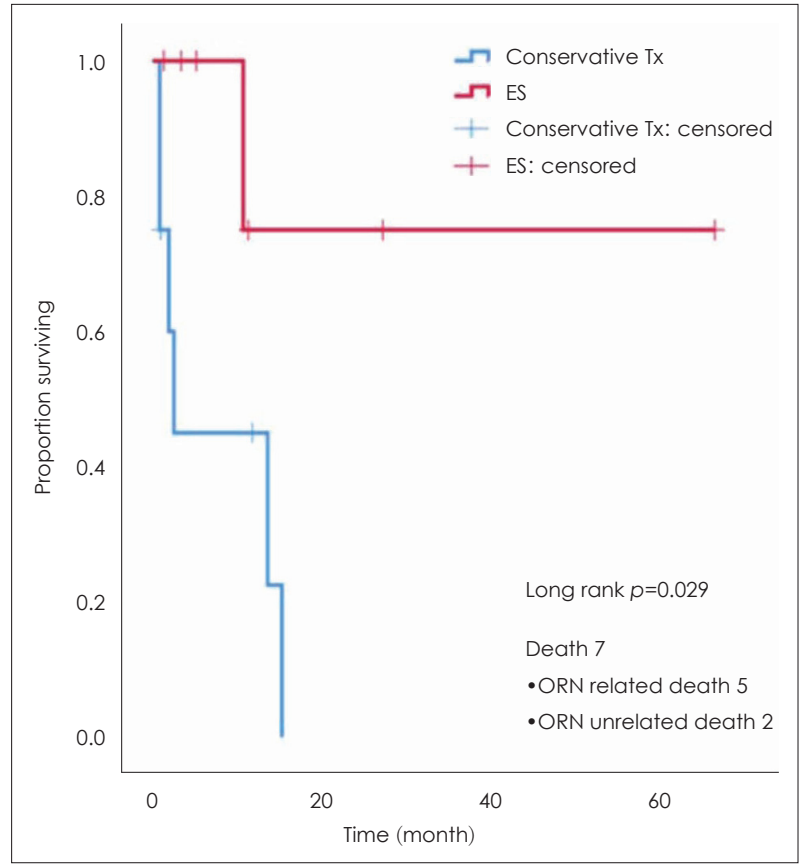

Fig. 7. Kaplan-Meier survival analysis of skull base osteoradionecrosis patients. There is a statistically significant difference in overall survival rate according to the extent of treatment. Tx: treatment, ES: endoscopic sequestration, ORN: osteoradionecrosis.

의 혈관외막(adventitia)이 괴사되고 약하기 때문에 최소한의 조작만으로도 경동맥 파열이 일어날 수 있다. 따라서 영상에 서 경동맥의 침범이 있다면, 질병의 크기와 상관없이 경동맥 에 인접한 경우에 조영술과 풍선폐쇄검사 및 양전자단층촬 영을 하여 측부 순환을 평가해야 하고 동시에, 경동맥 파열 로 인한 대량의 비출혈의 가능성에 대해서 환자와 보호자에 게 충분한 설명이 되어야 한다. 풍선폐쇄검사상 양전자단층 촬영에서 저관류가 관찰되지 않은 환자들에게는 코일 색전 술을 이용한 결찰을 수술 전에 시행할 수 있다. 만약 풍선폐 쇄검사에서 저관류가 관찰되는 경우 외경동맥과 내경동맥의 
우회로 이식술(ECA-ICA bypass)을 고려해 볼 수 있다. 두개저 방사선골괴사는 치료가 어렵고, 여려 보존적 방법이 있지만 가능하다면 적극적으로 부골절제술을 고려해야 하며, 만약 부골 절제술을 시행할 경우라면 혈류가 풍부한 조직으 로 덮어주어야 한다. 내경동맥이 침범된 경우 적절한 측부 순 환 여부에 따라 내경동맥에 대한 적절한 조치는 필수적이다.

\section{Acknowledgments}

None.

\section{Author Contribution}

Conceptualization: Tae-Bin Won. Data curation: Sung-Woo Cho, Tae-Bin Won. Formal analysis: Sung-Woo Cho, Tae-Bin Won. Investigation: Tae-Bin Won. Methodology: Sung-Woo Cho, Tae-Bin Won. Supervision: Tae-Bin Won. Visualization: Tae-Bin Won. Writing - original draft: Sung-Woo Cho, Tae-Bin Won. Writingreview \& editing: Sung-Woo Cho, Tae-Bin Won.

\section{ORCID}

Sung-Woo Cho

https://orcid.org/0000-0003-0827-4471

Tae-Bin Won

\section{REFERENCES}

1) Chang KP, Tsang NM, Chen CY, Su JL, Hao SP. Endoscopic management of skull base osteoradionecrosis. Laryngoscope 2000;110(7):1162-5.

2) Liu J, Ning $X$, Sun $X$, Lu H, Gu Y, Wang D. Endoscopic sequestrectomy for skull base osteoradionecrosis in nasopharyngeal carcinoma patients: A 10-year experience. Int J Clin Oncol 2019; 24(3):248-55.

3) Gossman W, Hanley ME, Cooper JS. Osteoradionecrosis [Internet]. Treasure Island, FL: StatPearls Publishing;2019 Dec 19 [cited 2020 Jan 15]. Available from: URL: https://www.ncbi.nlm.nih.gov/ books/NBK430818/.

4) Raggio BS, Winters R. Modern management of osteoradionecrosis. Curr Opin Otolaryngol Head Neck Surg 2018;26(4):254-9.

5) Rivero JA, Shamji O, Kolokythas A. Osteoradionecrosis: A review of pathophysiology, prevention and pharmacologic management using pentoxifylline, $\alpha$-tocopherol, and clodronate. Oral Surg Oral Med Oral Pathol Oral Radiol 2017;124(5):464-71.

6) Martos-Fernández M, Saez-Barba M, López-López J, EstrugoDevesa A, Balibrea-Del-Castillo JM, Bescós-Atín C. Pentoxifylline, tocopherol, and clodronate for the treatment of mandibular osteoradionecrosis: A systematic review. Oral Surg Oral Med Oral Pathol Oral Radiol 2018;125(5):431-9.

7) Buglione M, Cavagnini R, Di Rosario F, Maddalo M, Vassalli L, Grisanti S, et al. Oral toxicity management in head and neck cancer patients treated with chemotherapy and radiation: Xerostomia and trismus (Part 2). Literature review and consensus statement. Crit Rev Oncol Hematol 2016;102:47-54.

8) Lyons A, Ghazali N. Osteoradionecrosis of the jaws: Current understanding of its pathophysiology and treatment. Br J Oral Maxillofac Surg 2008;46(8):653-60.

9) Dhanda J, Pasquier D, Newman L, Shaw R. Current concepts in osteoradionecrosis after head and neck radiotherapy. Clin Oncol ( $\mathrm{R}$ Coll Radiol) 2016;28(7):459-66.

10) Caparrotti F, Huang SH, Lu L, Bratman SV, Ringash J, Bayley A, et al. Osteoradionecrosis of the mandible in patients with oropharyngeal carcinoma treated with intensity-modulated radiotherapy. Cancer

2017;123(19):3691-700.

11) Marx RE. A new concept in the treatment of osteoradionecrosis. J Oral Maxillofac Surg 1983;41(6):351-7.

12) Marx RE. Osteoradionecrosis: A new concept of its pathophysiology. J Oral Maxillofac Surg 1983;41(5):283-8.

13) Delanian S, Martin M, Bravard A, Luccioni C, Lefaix JL. Abnormal phenotype of cultured fibroblasts in human skin with chronic radiotherapy damage. Radiother Oncol 1998;47(3):255-61.

14) Delanian S. Striking regression of radiation-induced fibrosis by a combination of pentoxifylline and tocopherol. Br J Radiol 1998; 71(848):892-4.

15) Wang TH, Liu CJ, Chao TF, Chen TJ, Hu YW. Risk factors for and the role of dental extractions in osteoradionecrosis of the jaws: A national-based cohort study. Head Neck 2017;39(7):1313-21.

16) Sathasivam HP, Davies GR, Boyd NM. Predictive factors for osteoradionecrosis of the jaws: A retrospective study. Head Neck 2018;40(1):46-54.

17) Goldwaser BR, Chuang SK, Kaban LB, August M. Risk factor assessment for the development of osteoradionecrosis. J Oral Maxillofac Surg 2007;65(11):2311-6.

18) Huang XM, Zheng YQ, Zhang XM, Mai HQ, Zeng L, Liu X, et al. Diagnosis and management of skull base osteoradionecrosis after radiotherapy for nasopharyngeal carcinoma. Laryngoscope 2006; 116(9):1626-31.

19) Kolokythas A, Rasmussen JT, Reardon J, Feng C. Management of osteoradionecrosis of the jaws with pentoxifylline-tocopherol: A systematic review of the literature and meta-analysis. Int $\mathrm{J}$ Oral Maxillofac Surg 2019;48(2):173-80.

20) Magremanne M. Successful treatment of grade III osteoradionecrosis with mandibular fracture with pentoxifylline, tocopherol and clodronate. J Stomatol Oral Maxillofac Surg 2018;119(6):518-22.

21) Aggarwal K, Goutam M, Singh M, Kharat N, Singh V, Vyas S, et al. Prophylactic use of pentoxifylline and tocopherol in patients undergoing dental extractions following radiotherapy for head and neck cancer. Niger J Surg 2017;23(2):130-3.

22) Delanian S, Balla-Mekias S, Lefaix JL. Striking regression of chronic radiotherapy damage in a clinical trial of combined pentoxifylline and tocopherol. J Clin Oncol 1999;17:3283-90.

23) Lyons A, Osher J, Warner E, Kumar R, Brennan PA. Osteoradionecrosis--a review of current concepts in defining the extent of the disease and a new classification proposal. Br J Oral Maxillofac Surg 2014;52(5):392-5.

24) Glicksman JT, Khalili S, Fung K, Parnes LS, Agrawal SK. Pentoxifylline-tocopherol-clodronate combination: A novel treatment for osteoradionecrosis of the temporal bone. Head Neck 2015;37(12):E191-3.

25) Robard L, Louis MY, Blanchard D, Babin E, Delanian S. Medical treatment of osteoradionecrosis of the mandible by PENTOCLO: preliminary results. Eur Ann Otorhinolaryngol Head Neck Dis 2014;131(6):333-8.

26) Delanian S, Chatel C, Porcher R, Depondt J, Lefaix JL. Complete restoration of refractory mandibular osteoradionecrosis by prolonged treatment with a pentoxifylline-tocopherol-clodronate combination (PENTOCLO): A phase II trial. Int J Radiat Oncol Biol Phys 2011; 80(3):832-9.

27) Delanian S, Lefaix JL. Complete healing of severe osteoradionecrosis with treatment combining pentoxifylline, tocopherol and clodronate. Br J Radiol 2002;75(893):467-9.

28) Delanian S, Depondt J, Lefaix JL. Major healing of refractory mandible osteoradionecrosis after treatment combining pentoxifylline and tocopherol: A phase II trial. Head Neck 2005;27(2):114-23.

29) Jenwitheesuk K, Mahakkanukrauh A, Punjaruk W, Jenwitheesuk K, Chowchuen B, Jinaporntham S, et al. Efficacy of adjunctive hyperbaric oxygen therapy in osteoradionecrosis. Biores Open 
Access 2018;7(1):145-9

30) Bennett MH, Feldmeier J, Hampson NB, Smee R, Milross C. Hyperbaric oxygen therapy for late radiation tissue injury. Cochrane Database Syst Rev 2016;4:CD005005.

31) Annane D, Depondt J, Aubert P, Villart M, Géhanno P, Gajdos P, et al. Hyperbaric oxygen therapy for radionecrosis of the jaw: A randomized, placebo-controlled, double-blind trial from the ORN96 study group. J Clin Oncol 2004;22(24):4893-900.

32) Huang WB, Wong STS, Chan JYW. Role of surgery in the treatment of osteoradionecrosis and its complications after radiotherapy for nasopharyngeal carcinoma. Head Neck 2018;40(2):369-76.

33) Kalra GS, Midya M, Bedi M. Access to the skull base - maxillary swing procedure - long term analysis. Ann Maxillofac Surg 2018; 8(1):86-90.

34) Choi NY, Kim HJ, Baek CH. Surgical management of extensive osteoradionecrosis in nasopharyngeal carcinoma patients with the maxillary swing approach and free muscular flaps. Clin Otolaryngol 2017;42(5):1100-4.

35) Yarnold J, Brotons MC. Pathogenetic mechanisms in radiation fibrosis. Radiother Oncol 2010;97(1):149-61.

36) Chen MY, Mai HQ, Sun R, Guo X, Zhao C, Hong MH, et al. Clinical findings and imaging features of 67 nasopharyngeal carcinoma patients with postradiation nasopharyngeal necrosis. Chin J Cancer 2013;32(10):533-8.

37) AlQahtani A, Castelnuovo P, Nicolai P, Prevedello DM, Locatelli $D$, Carrau RL. Injury of the internal carotid artery during endoscopic skull base surgery: Prevention and management protocol. Otolaryngol Clin North Am 2016;49(1):237-52.

38) Maras D, Lioupis C, Magoufis G, Tsamopoulos N, Moulakakis K, Andrikopoulos V. Covered stent-graft treatment of traumatic internal carotid artery pseudoaneurysms: A review. Cardiovasc Intervent Radiol 2006;29(6):958-68.

\section{정답 및 해설}

해 설 섬유성 이형성증(fibrous dysplasia)은 단골성, 다골성, 파종성 3종류로 분류할 수 있다. 단골성 섬유성 이형성증은 하나의 골성 구조만 침범하는 것으로 전체 섬유성 이형성증의 17 70\%가량 차지하며 다골성 섬유성 이형성증은 여러 개의 골성 구조에 병변이 발생하는 것을 말하며 30 51\%가량을 차지한다. 파종성 섬유성 이형성증은 피부 색소 병변 및 내분비 기능 이상 등의 골외 증상을 동반하고 여러 골성 구조를 침범하는 질환으로 $3 \sim 32 \%$ 가량을 차지한다. 섬유성 이형성증은 대부 분 팔다리의 장골(long bone in the arms or leg)이나 skullo에 잘 발생하나, 드물게 부비동을 침범하는 경우에는 전두동 단 독 침범이 가장 흔하며, 전두동, 사골동 동시 침범, 상악동 단독 침범순으로 발생하고 사골동이나 접형동 단독으로 침범하 는 경우는 매우 드물다. 임상 증상은 대개 비특이적으로 무증상인 경우가 가장 많으며, 대부분 무증상인 특성상 우연히 방 사선 촬영에서 발견되는 경우가 흔하다. 섬유성 이형성증의 진단은 임상 증상, 방사선학적 검사, 조직학적 검사를 바탕으로 하며, 치료는 병변의 증식이 종료될 때까지 연기를 권하며, 증식이 정지된 무증상의 작은 단일 국소병변은 치료할 필요가 없다. 안구돌출, 시력저하, 안면 변형 등의 미용상, 기능상의 합병증이 동반되는 경우에는 수술적 절제를 시행한다. 절제범 위는 종양의 발생 위치나 중요 구조물과의 근접성, 증상의 정도를 고려하여 결정하고, 완전절제가 불가능한 경우 부분절제 나 소파술을 시행한다. 